\title{
Pengaruh PAD, Dana Perimbangan dan PMA terhadap Tingkat Kemajuan Daerah Kabupaten dan Kota di Provinsi Sulavesi Selatan
}

\author{
Oleh: Muhammad Syukri dan Didiharyono \\ (Universitas Andi Djemma Palopo)
}

\begin{abstract}
The purpose of this study is to determine the effect of locally-generated revenue (PAD), balancing funds and Foreign Direct Investment (FDI) to Progress Regions Level districts and cities in South Sulawesi Province either simultaneously or partially. Type of research used is applied research with quantitative data. The data used obtained from the Statistics Central Institution (BPS), which covers 24 districts and cities of South Sulawesi Province in 2016 in the form of thousands of rupiah. The research procedure is (1) Descriptive Analysis. (2) Establish multiple regression model. (3) Partial test and simultaneous test, and (4) determine the coefficient determination. Based on the simultaneous test of multiple linear regression model that PAD (X1), Balance Funds (X2) and FDI (X3) have significant effect to regional progress level (Y). And partial model testing, only PAD (X1) and fund balancing (X2) which significantly influence to regional progress level (Y). Meanwhile, FDI (X3) has no significant effect on regional progress level (Y). Therefore, the cultivation of FDI should be targeted and can provide direct benefits for the community in improving their welfare that will impact on improving regional progress. The suggestions needed in the development of further research that is required addition of other variables that can affect the level of regional progress.
\end{abstract}

Keyword: PAD, Balance Funds, FDI and Regional Progress Level

\begin{abstract}
ABSTRAK
Tujuan dari penelitian ini yaitu untuk mengetahui pengaruh Pendapatan Asli Daerah (PAD), dana perimbangan dan Penanaman Modal Asing (PMA) terhadap Tingkat Kemajuan Daerah kabupaten dan kota di Provinsi Sulavesi Selatan baik secara simultan maupun secara parsial. Jenis penelitian yang digunakan adalah penelitian terapan (applied research) dengan data kuantitatif. Data yang digunakan bersumber dari Badan Pusat Statistik (BPS) yaitu meliputi 24 Kabupaten dan Kota Provinsi Sulawesi Selatan Tahun 2016 dalam bentuk ribuan rupiah. Prosedur penelitian yang dilakukan yaitu (1) Analisis Deskriptif. (2) Membentuk model regresi berganda. (3) Uji parsial dan uji simultan, dan (4) menentukan koefisien determinasi. Berdasarkan siginfikansi pengujian model regresi linear berganda secara simultan bahwa PAD $\left(\mathrm{X}_{1}\right)$, dana perimbangan $\left(\mathrm{X}_{2}\right)$ dan PMA $\left(\mathrm{X}_{3}\right)$ berpengaruh secara signifikan terhadap tingkat kemajuan daerah $(\mathrm{Y})$. Dan pengujian model secara parsial, hanya $\mathrm{PAD}\left(\mathrm{X}_{1}\right)$ dan dana perimbangan $\left(\mathrm{X}_{2}\right)$ yang berpengaruh secara signifikan terhadap tingkat kemajuan daerah (Y). Sedangkan, PMA $\left(\mathrm{X}_{3}\right)$ tidak berpengaruh secara signifikan terhadap tingkat kemajuan daerah $(\mathrm{Y})$. Oleh karena itu, penanaman PMA harus tepat sasaran dan dapat memberikan manfaat secara langsung bagi masyarakat dalam peningkatan kesejahteraannya yang akan berdampak pada peningkatan kemajuan daerah. Adapun saran yang perlukan dalam pengembangan
\end{abstract}


penelitian selanjutnya yaitu diperlukan penambahan variabel-variabel lainnya yang dapat mempengaruhi tingkat kemajuan daerah.

Kata Kunci: PAD, Dana Perimbangan, PMA dan Tingkat Kemajuan Daerah

\section{PENDAHULUAN}

Pembangunan nasional merupakan proses multidimensial yang meliputi perubahan struktur sosial, perubahan dalam sikap hidup masyarakat dan perubahan dalam kelembagaan secara nasional. Pembangunan nasional meliputi perubahan dalam tingkat pertumbuhan ekonomi, pengurangan ketimpangan pendapatan, peningkatan kemajuan daerah dan pemberantasan kemiskinan. Salah satu indikator untuk mengukur keberhasilan pembangunan dalam suatu Negara adalah pertumbuhan ekonomi. Pertumbuhan ekonomi merupakan tingkat pertambahan dari pendapatan nasional yang akan berdampak pada peningkatan kemajuan masing-masing daerah.

Pemerintah daerah sebagai subsistem negara memiliki tanggung jaawa yang besar dalam meningkatkan daya guna dan hasil guna penyelenggaraan pemerintahan dan pelayanan masyarakat di daerah. Sebagai daerah otonom, ia mempunyai kewenangan dan tanggung jawab untuk menyelenggarakan kepentingan masyarakat dan mencukupi kesejahteraan masyarakat (Novianto, 2013). Daerah otonom atau biasa disebut juga sebagai otonomi daerah (Otda) merupakan salah satu bentuk dari program pemerintah yang bertujuan untuk menyelesaikan permasalahan daerah dalam mengelola informasi kedaerahan. Tidak hanya itu, dengan Otda dapat membuat pemerintah daerah berada dalam kondisi yang lebih baik dan dapat memobilisasi sumber daya secara mandiri sehingga dapat mencapai tujuan dalam peningkatan pembangunan daerah. Di dalam TAP MPR No. IV/MPR/2000 ditegaskan bahwasanya "Kebijakan desentralisasi ke daerah diarahkan untuk mencapai peningkatan pelayanan publik dan pengembangan kreativitas Pemerintah daerah, keselarasan hubungan antara Pusat dan Daerah serta antar daerah itu sendiri dalam kewenangan dan keuangan untuk menjamin peningkatan rasa kebangsaan, demokrasi dan kesejahteraan serta penciptaan ruang yang lebih luas bagi kemandirian daerah".

Penyelenggaraan Otda dan desentralisasi fiskal yang luas dan bertanggung jawab diperlukan kewenangan dan kemampuan untuk menggali sumber keuangan sendiri. Pendapatan Asli Daerah (PAD) merupakan salah satu sumber utama pendapatan yang diperoleh daerah yang dipungut berdasarkan peraturan daerah sesuai dengan peraturan perundang-undangan. Dengan adanya desentralisasi fiskal, daerah mempunyai kewenangan yang lebih besar untuk mengoptimalkan PAD-nya. Peningkatan PAD yang dianggap sebagai modal, yang secara akumulasi akan lebih banyak menimbulkan eksternalitas yang bersifat positif dan akan mempercepat pertumbuhan ekonomi (Pujiati, 2008).

Saat pelaksanaan desentralisasi fiskal tahun 2006-2009, penerimaan daerah yang bersumber dari dana perimbangan mengalami peningkatan dari tahun ke tahun, namun pertumbuhan ekonomi justru mengalami fluktuasi. Hal ini mengindikasikan bahwa dengan adanya dana perimbangan yang tinggi, ketergantungan daerah terhadap dana perimbangan menjadi sangat tinggi dan kemandirian daerah penghasil PAD semakin menurun. Secara teoritis pengukuran kemandirian daerah diukur dari Pendapatan Asli Daerah (PAD). Sumber PAD berasal dari pajak daerah, hasil retribusi daerah, hasil 
perusahaan milik daerah, hasil pengolahan kekayaan daerah lainnya yang dipisahkan, dan lain-lain pendapatan daerah yang sah (Azzumar, 2011).

Pendapatan Asli Daerah di Sulawesi Selatan dari tahun ke tahun mengalami peningkatan yang cukup signifikan sebagaimana ditunjukan pada Grafik Gambar 1 yang merupakan realisasi pendapatan asli daerah pemerintah Provinsi Sulawesi Selatan (ribu rupiah) dari Tahun 2012-2016.

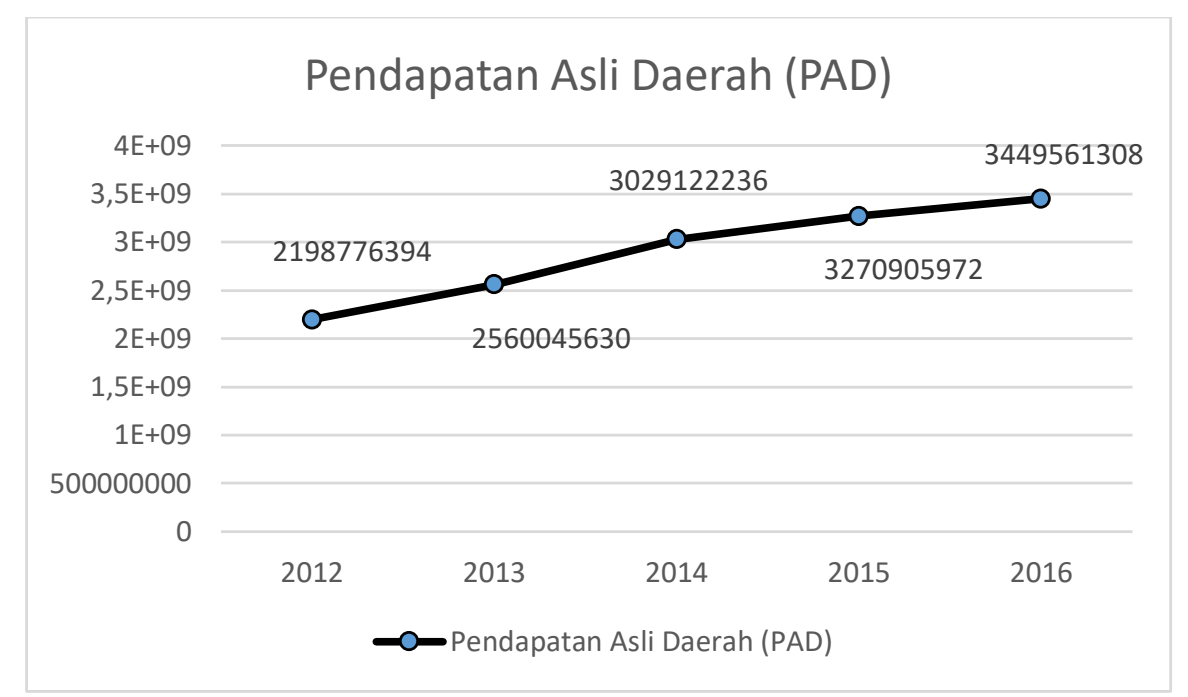

Sumber: Diolah Berdasarkan Data BPS Sulsel, 2013-2017

Gambar 1. PAD Sulsel 2012-2016

Salah satu tujuan instrumen fiskal dari dana perimbangan yaitu digunakan untuk mendorong pertumbuhan ekonomi melalui belanja pembangunan dan investasi swasta. Kontribusi belanja pembangunan akan menarik investor untuk dapat berinvestasi di daerah sehingga akan memperluas basis kegiatan ekonomi di berbagai sektor dan secara khusus memperluas lapangan usaha dan menurunkan tingkat pengangguran. Dana Perimbangan adalah dana yang bersumber dari APBN yang dialokasikan kepada daerah untuk mendanai kebutuhan daerah dalam rangka pelaksanaan desentralisasi. Dana perimbangan bertujuan mengurangi kesenjangan fiskal antara pemerintah pusat dan pemerintah daerah, dan antar pemerintah daerah dalam pengembangan perekonomian dan peningkatan kemajuan daerah. Adapun jenis-jenis dana perimbangan meliputi Dana Bagi Hasil (DBH), Dana Alokasi Umum (DAU), Dana Alokasi Khusus (DAK) (Novalia, 2016).

Begitu pula dengan dana Perimbangan di Sulawesi Selatan dari tahun ke tahun mengalami peningkatan yang cukup signifikan sebagaimana ditunjukan pada Grafik pada Gambar 2 yang merupakan realisasi dana perimbangan pemerintah Provinsi Sulawesi Selatan (ribu rupiah) dari Tahun 2012-2016. 


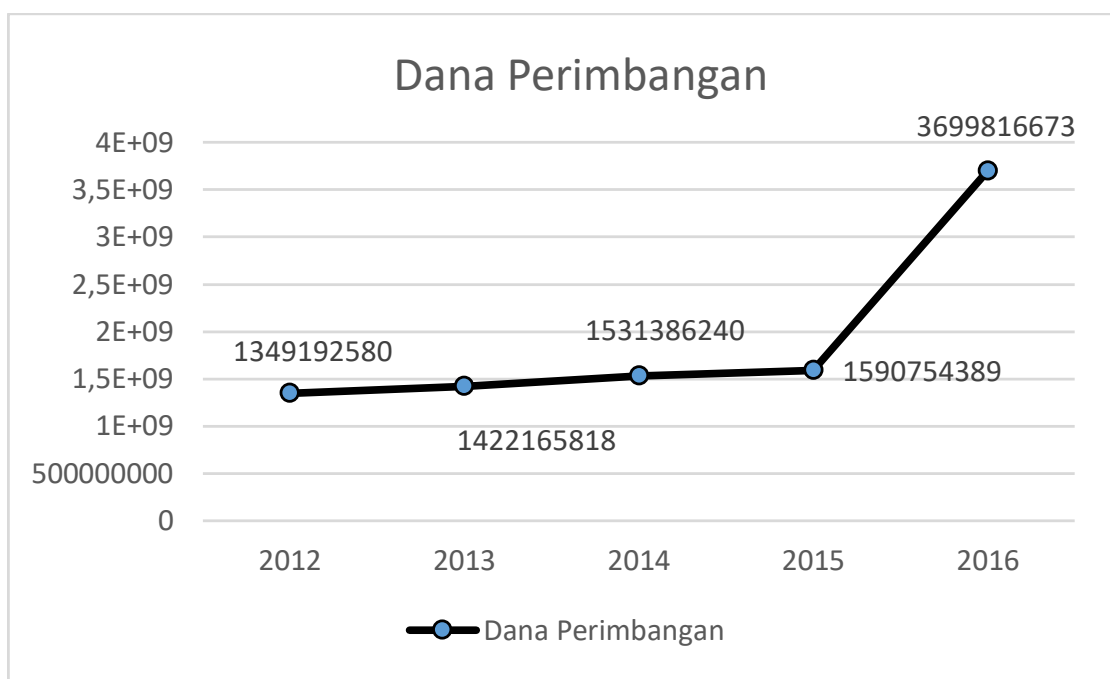

Sumber: Diolah Berdasarkan Data BPS Sulsel, 2013-2017

Gambar 2. Dana Perimbangan Sulsel 2012-2016

Kegiatan investasi (penanaman modal) termasuk investasi asing dan investasi swasta akan berpengaruh terhadap pertumbuhan ekonomi, yaitu meningkatnya ketersediaan kapasitas produksi barang dan jasa yang dibutuhkan masyarakat. Maurer (2009) menyatakan bahwa dalam konsep teori ekonomi menawarkan berbagai pendekatan dalam menggambarkan hubungan antara kegiatan investasi terhadap pertumbuhan ekonomi khususnya dalam kajian ekonomi makro. Kegiatan investasi memungkinkan suatu masyarakat terus menerus meningkatkan kegiatan ekonomi dan tingkat kemajuan daerah, meningkatkan pendapatan nasional dan meningkatkan taraf kemakmuran masyarakat. Peranan ini bersumber dari tiga fungsi penting dari kegiatan investasi yakni (1) investasi merupakan salah satu komponen dari pengeluaran agregat, sehingga kenaikan investasi akan meningkatkan permintaan agregat, pendapatan nasional serta kesempatan kerja; (2) pertambahan barang modal sebagai akibat investasi akan menambah kapasitas produksi; dan (3) investasi selalu diikuti oleh perkembangan teknologi.

Dalam membiayai investasi infrastruktur daerah, perlu juga mengatur sumber daya dari sektor swasta. Hal ini membutuhkan pembentukan kelembagaan dan peraturan lingkungan yang dapat menarik investasi swasta dalam bidang infrastruktur, merubah hukum dan peraturan perundang-undangan, mengenalkan konsep pemberian harga yang merefleksikan biaya (cost-reflective pricing) dan menyediakan prosedur dan proses privatisasi atau disinvestasi yang transparan. Reformasi semacam ini juga berkontribusi dalam meningkatkan keakuntabilitasan sektor publik dan menyediakan pelayanan publik yang lebih baik (Azzumar, 2011).

Peranan investasi terhadap kapasitas produksi memang sangat besar, karena investasi merupakan penggerak perekonomian demi terciptanya kemajuan daerah, baik untuk penambahan faktor produksi maupun berupa peningkatan kualitas faktor produksi. Investasi ini nantinya akan memperbesar pengeluaran masyarakat melalui peningkatan pendapatan masyarakat dengan cara multiplier effect. Faktor produksi akan mengalami penyusutan, sehingga akan mengurangi produktivitas dari faktor-faktor produksi tersebut. Supaya tidak terjadi penurunan produktivitas harus diimbangi dengan investasi 
baru yang lebih besar dari penyusutan faktor produksi tersebut (Novianto, 2013). Sebagai contoh dengan menciptakan kompetisi yang transparan diantara pihak swasta untuk menyediakan layanan publik, diharapkan dapat membantu mengatasi aspek korupsi yang mungkin terjadi. Meningkatkan kompetisi dapat meningkatkan mutu dan efisiensi serta pengurangan harga di daerah-daerah yang didominasi perusahaan daerah yang tidak efisien. Selain itu juga, pengenalan konsep sanksi yang didukung oleh bantuan yang berdasarkan output-based akan membantu meningkatkan akses terhadap layanan umum dengan harga terendah. Secara umum, partisipasi swasta yang efisien dapat membebaskan beban fiskal di pemerintah daerah dan membebaskan sumber daya umum untuk program-program prioritas (Agustino, 2005).

Yang menjadi objek penelitian dalam artikel ini adalah tingkat Kemajuan Daerah. Indikator Kemajuan Daerah merupakan parameter yang dijadikan sebagai acuan bagi suatu daerah untuk pembangunan wilayah demi terwujudnya suatu daerah yang berkemajuan yang berdampak pada kesejahteraan di daerah tersebut. Tingkat kemajuan daerah dihitung berdasarkan total persentase peningkatan berbagai sektor, diantarnya sektor industri, pertanian, pertambangan, infrastruktur (ketersediaan air, listrik, gas, dan rata-rata kelaikan bangunan), perdagangan, pariwisata, transportasi, jasa dan termasuk dalam bidang pendidikan. Berdasarkan penjelasan di atas maka tujuan dari penelitian ini yaitu untuk mengetahui pengaruh Pendapatan Asli Daerah (PAD), dana perimbangan dan Penanaman Modal Asing (PMA) terhadap Tingkat Kemajuan Daerah kabupaten dan kota di Provinsi Sulavesi Selatan baik secara simultan maupun secara parsial.

\section{METODE PENELITIAN}

Jenis penelitian yang digunakan adalah penelitian terapan (applied research) dengan data kuantitatif. Data yang digunakan bersumber dari Badan Pusat Statistik (BPS) yaitu meliputi 24 kabupaten/kota Provinsi Sulawesi Selatan Tahun 2016 dalam bentuk ribuan rupiah. Adapun variabel respon dalam penelitian ini adalah tingkat kemajuan daerah (Y). Sedangkan, variabel prediktor terdiri atas pendapatan asli daerah $\left(\mathrm{X}_{1}\right)$, dana perimbangan $\left(\mathrm{X}_{2}\right)$ dan penanaman modal asing $\left(\mathrm{X}_{3}\right)$. Prosedur penelitian yang dilakukan yaitu (1) Analisis Deskriptif. (2) Membentuk model regresi berganda. (3) Uji parsial dan uji simultan, dan (4) menentukan koefisien determinasi.

\section{HASIL PENELITIAN DAN PEMBAHAN}

\section{Statistik deskriptif}

Tabel 1 berikut adalah statistik deskriptif untuk variabel respon dan variabel prediktor yang meliputi $\mathrm{N}$ data, nilai maksimum, nilai minimum, nilai rata-rata (mean) dan nilai standar deviasi. Variabel prediktor dalam penelitian ini terdiri atas pendapatan asli daerah $\left(\mathrm{X}_{1}\right)$, dana perimbangan $\left(\mathrm{X}_{2}\right)$ dan penanaman modal asing $\left(\mathrm{X}_{3}\right)$. Dan variabel respon yaitu tingkat kemajuan daerah $\left(\mathrm{Y}_{3}\right)$. 
Tabel 1. Statistik deskriptif variabel respon

\begin{tabular}{|c|c|c|c|c|c|}
\hline Variabel & $\mathrm{N}$ & Minimum & Maximum & Mean & Std. Deviation \\
\hline X1 & 24 & $3 . \mathrm{E} 7$ & $8 . \mathrm{E} 9$ & $9.62 \mathrm{E} 8$ & $2.094 \mathrm{E} 9$ \\
$\mathrm{X} 2$ & 24 & $2 . \mathrm{E} 7$ & $8 . \mathrm{E} 9$ & $1.07 \mathrm{E} 9$ & $1.577 \mathrm{E} 9$ \\
$\mathrm{X} 3$ & 24 & 0 & $7 . \mathrm{E} 7$ & $9.56 \mathrm{E} 6$ & $1.800 \mathrm{E} 7$ \\
Y & 24 & $3 . \mathrm{E} 9$ & $9 . \mathrm{E} 10$ & $1.05 \mathrm{E} 10$ & $1.710 \mathrm{E} 10$ \\
Valid N (listwise) & 24 & & & & \\
\hline
\end{tabular}

\section{Model Regresi Linear Berganda}

Perhitungan statistik dalam analisis regresi linear berganda yaitu dengan menggunakan bantuan sofeware komputer atau aplikasi SPSS. Hasil pengolahan data dengan menggunakan program SPSS selengkapnya dapat dilihat pada Tabel 2 berikut.

Tabel 2. Model Regresi Linear Berganda

\begin{tabular}{|c|c|c|c|c|c|c|}
\hline \multicolumn{7}{|c|}{ Coefficients $^{a}$} \\
\hline \multirow{2}{*}{\multicolumn{2}{|c|}{ Model }} & \multicolumn{2}{|c|}{ Unstandardized Coefficients } & $\begin{array}{c}\text { Standardized } \\
\text { Coefficients }\end{array}$ & \multirow[b]{2}{*}{$\mathrm{T}$} & \multirow[b]{2}{*}{ Sig. } \\
\hline & & $\mathrm{B}$ & Std. Error & Beta & & \\
\hline \multirow[t]{4}{*}{1} & (Constant) & 8.254E9 & 2.305E9 & & 3.582 & .002 \\
\hline & $\mathrm{X} 1$ & 9.303 & 1.157 & 1.139 & 8.039 & .000 \\
\hline & $\mathrm{X} 2$ & -6.250 & 1.483 & -.576 & -4.215 & .000 \\
\hline & X3 & -3.858 & 103.678 & -.004 & -.037 & .971 \\
\hline
\end{tabular}

a. Dependent Variable: $Y$

Berdasarkan Tabel 2 di atas, maka model regresi linear berganda dapat ditulis yaitu.

$$
Y=8.254 E 9+9.303 X_{1}-6.250 X_{2}-3.858 X_{3}
$$

Persamaan analisis regresi tersebut dapat dijelaskan sebagai berikut: (a) Konstanta sebesar $8.254 E 9$ artinya jika nilai variabel prediktor nilainya 0 , maka variabel respon tetap konstan yaitu dengan nilainya 8.254E9. (b) Jika koefisien regresi untuk variabel rediktor bertambah satu satuan maka akan mempengaruhi peningkatan nilai pada variabel respon (Y).

\section{Uji Signifikansi Simultan (Uji-F).}

Pengujian model secara serentak dilakukan untuk mengetahui apakah secara keseluruhan variabel prediktor berpengaruh secara signifikan terhadap variabel respon. Dengan hipotesis yaitu

$\mathrm{H}_{0}: \hat{\beta}_{p q}=0$ (parameter regresi prediktor $p$ terhadap respon $q$ tidak berpengaruh secara signifikan) 
$\mathrm{H}_{1}: \hat{\beta}_{p q} \neq 0$ (parameter regresi prediktor $p$ terhadap respon $q$ berpengaruh secara signifikan) dimana $p=1,2,3$ dan $q=1$.

Keputusan uji yaitu jika nilai Sig. $<\alpha$, dimana $\alpha$ adalah 0.05 atau F-hitung $>$ F-tabel dengan $\alpha=0.05$ maka keputusannya adalah menolak $\mathrm{H}_{0}$ atau menerima $\mathrm{H}_{1}$. Perhatikan Tabel 3 berikut!

Tabel 3. Analisis of Varians

ANOVA $^{b}$

\begin{tabular}{|c|c|c|c|c|c|c|}
\hline \multicolumn{2}{|c|}{ Model } & Sum of Squares & Df & Mean Square & $\mathrm{F}$ & Sig. \\
\hline \multirow[t]{3}{*}{1} & Regression & 5.312E21 & 3 & 1.771E21 & 25.017 & $.000^{\mathrm{a}}$ \\
\hline & Residual & 1.416E21 & 20 & 7.078E19 & & \\
\hline & Total & $6.728 \mathrm{E} 21$ & 23 & & & \\
\hline
\end{tabular}

Berdasarkan Tabel 3 di atas, diperoleh bahwa nilai Sig. $<\alpha$ yaitu $0.00<0.05$ dan nilai F-hitung > F-tabel yaitu $25.017>3.40$, maka keputusannya adalah menolak $\mathrm{H}_{0}$. Sehingga dapat disimpulkan bahwa seluruh variabel prediktor berpengaruh signifikan terhadap variabel respon secara simultan atau dengan kata lain bahwa Pendapatan asli daerah, dana perimbangan dan penanaman modal asing berpengaruh secara signifikan terhadap tingkat kemajuan daerah seluruh kabupaten dan kota di provinsi Sulavesi Selatan.

\section{Uji Signifikansi Parsial (Uji-t)}

Pengujian signifikansi secara parsial bertujuan untuk melihat sejauh mana pengaruh signifikan setiap variabel prediktor terhadap variabel-variabel respon secara parsial. Dengan hipotesis yaitu

$\mathrm{H}_{0}: \hat{\beta}_{p q}=0$ (parameter regresi prediktor $p$ terhadap respon $q$ tidak berpengaruh secara signifikan)

$\mathrm{H}_{1}: \hat{\beta}_{p q} \neq 0$ (parameter regresi prediktor $p$ terhadap respon $q$ berpengaruh secara signifikan) dimana $p=1,2,3$ dan $q=1$.

Keputusan uji yaitu jika memenuhi nilai $\operatorname{Sig}<\alpha$, dengan $\alpha$ yaitu 0.05 atau $t$-hitung $>t$ tabel maka keputusannya adalah menolak $\mathrm{H}_{0}$ atau menerima $\mathrm{H}_{1}$.

\section{Pengaruh PAD $\left(\mathbf{X}_{1}\right)$ terhadap Tingkat Kemajuan Daerah (Y)}

Berdasarkan Tabel 2, didapatkan nilai Sig. untuk variabel PAD $\left(\mathrm{X}_{1}\right)$ sebesar 0.000 . Karena nilai Sig. $<\alpha$ yaitu $0.000<0.05$, maka berhasil menolak $\mathrm{H}_{0}$ sehingga parameter variabel prediktor $p$ berpengaruh secara signifikan terhadap variabel respon $q$ atau PAD berpengaruh signifikan terhadap tingkat kemajuan daerah.

\section{Pengaruh Dana Perimbangan $\left(\mathrm{X}_{2}\right)$ terhadap Tingkat Kemajuan Daerah (Y)}

Berdasarkan Tabel 2, didapatkan nilai Sig. untuk variabel PAD $\left(\mathrm{X}_{1}\right)$ sebesar 0.000 . Karena nilai Sig. $<\alpha$ yaitu $0.000<0.05$ ), maka berhasil menolak $\mathrm{H}_{0}$ sehingga 
parameter variabel prediktor $p$ berpengaruh secara signifikan terhadap variabel respon $q$ atau dana perimbangan berpengaruh signifikan terhadap tingkat kemajuan daerah.

\section{Pengaruh PMA $\left(\mathrm{X}_{1}\right)$ terhadap Tingkat Kemajuan Daerah (Y)}

Berdasarkan Tabel 2, didapatkan nilai Sig. untuk variabel PAD $\left(\mathrm{X}_{1}\right)$ sebesar 0.971 . Karena nilai Sig. $>\alpha$ yaitu $0.971>0.05$, maka berhasil menerima $\mathrm{H}_{0}$ sehingga parameter variabel prediktor $p$ berpengaruh secara signifikan terhadap variabel respon $q$ atau penanaman modal asing tidak berpengaruh signifikan terhadap tingkat kemajuan daerah. Setidaknya ada beberapa alasan mengapa PMA tidak berpengaruh signifikan terhadap tingkat kemajuan daerah diantaranya adalah investasi asing yang tidak tepat sasaran dan tidak menyentuh langsung lapisan masyarakat bawah, bahkan terkadang investasi asing melalui perusahaan asing hanya mencari keuntungan yang sebesarbesarnya dan keuntungannya dibawa ke negaranya masing-masing sehingga mengakibatkan kerugian dan kekecewaan bagi masyarakat atau bahkan pemerintahan daerah setempat.

\section{Koefesien Determinasi}

Koefisien determinasi (R-Squared) atau $\mathrm{R}^{2}$ merupakan suatu nilai yang menunjukkan besarnya derajat kemampuan menerangkan variabel prediktor terhadap variabel respon dari fungsi tersebut. Nilai R-Squared berkisar antara $0<\mathrm{R}^{2}<1$ dimana semakin mendekati 1 maka semakin dekat pula hubungan antara variabel prediktor dengan variabel respon atau dapat dikatakan model tersebut baik dan memiliki hubungan yang kuat, demikian pula sebaliknya. Nilai $\mathrm{R}^{2}$ juga yang semakin mendekati 1 berarti variabel independen memberikan hampir semua informasi yang di butuhkan untuk memprediksi variabel dependen. Koefisien determinasi yang di gunakan adalah nilai adjusted $\mathrm{R}$ square karena lebih dapat di percaya dalam mengevaluasi model regresi. Nilai adjusted $\mathrm{R}$ square dapat naik atau turun apabila suatu variabel independen di tambahkan ke dalam model.

Tabel 4. Koefesien Determinasi

\begin{tabular}{|c|c|c|c|c|}
\hline & & Model Summary \\
Model & $\mathrm{R}$ & $\mathrm{R}$ Square & $\begin{array}{c}\text { Adjusted } \mathrm{R} \\
\text { Square }\end{array}$ & $\begin{array}{c}\text { Std. Error of the } \\
\text { Estimate }\end{array}$ \\
\hline 1 & $.889^{\mathrm{a}}$ & .790 & .758 & $8.413 \mathrm{E} 9$ \\
\hline
\end{tabular}

a. Predictors: (Constant), X3, X2, X1

Hasil koefisien determinasi $\left(\mathrm{R}^{2}\right)$ dari model yang menunjukan seberapa besar kemampuan variabel prediktor dalam menjelaskan variabel respon dapat dilihat pada tabel 4. Dalam Tabel 4 menunjukan nilai koefisien determinasi $\left(\mathrm{R}^{2}\right)$ dari hasil estimasi model adalah sebesar 0.790 yang berarti $79 \%$ tingkat kemajuan daerah kabupaten dan kota provinsi Sulawesi Selatan dipengaruhi oleh PAD, dana perimbangan dan PMA. Sedangkan, sisanya sebesar $21 \%$ dipengaruhi oleh variabel lainnya di luar model penelitian ini. 


\section{SIMPULAN DAN SARAN}

Berdasarkan siginfikansi pengujian model regresi linear berganda secara simultan bahwa PAD $\left(\mathrm{X}_{1}\right)$, dana perimbangan $\left(\mathrm{X}_{2}\right)$ dan PMA $\left(\mathrm{X}_{3}\right)$ berpengaruh secara signifikan terhadap tingkat kemajuan daerah $(\mathrm{Y})$. Dan pengujian model secara parsial, hanya PAD $\left(\mathrm{X}_{1}\right)$ dan dana perimbangan $\left(\mathrm{X}_{2}\right)$ yang berpengaruh secara signifikan terhadap tingkat kemajuan daerah $(\mathrm{Y})$. Sedangkan, PMA $\left(\mathrm{X}_{3}\right)$ tidak berpengaruh secara signifikan terhadap tingkat kemajuan daerah (Y). Oleh karena itu, penanaman PMA harus tepat sasaran dan dapat memberikan manfaat secara langsung bagi masyarakat dalam peningkatan kesejahteraannya yang akan berdampak pada peningkatan kemajuan daerah. Adapun saran yang perlukan dalam pengembangan penelitian selanjutnya yaitu diperlukan penambahan variabel-variabel lainnya yang dapat mempengaruhi tingkat kemajuan daerah.

\section{DAFTAR PUSTAKA}

Azzumar, Mochamad Rizky. (2011). Pengaruh Pendapatan Asli Daerah, Dana Perimbangan, Investasi Swasta, Tenaga Kerja Terhadap Pertumbuhan Ekonomi Di Era Desentralisasi Fiskal Tahun 2005-2009 (Studi Kasus Kabupaten/Kota Provinsi Jawa Tengah). Skripsi Fakultas ekonomi universitas diponegoro semarang.

Didiharyono, D., Marsal, M., \& Nasruddin, N. (2017). Multivariate Regression Analysis with KICC Method In Measuring of Society Welfare In South Sulawesi. Journal of Math Sciences, 2(2), 5-13.

Maurer, Julia. 2009. The Effects Of Foreign Direct Investment In Urban Development: The Case Of Budapest. Development Planning Unit University College London. Working Paper No: 142

Mayasari, Luh Putu Rani dkk. (2014). Pengaruh Pertumbuhan Ekonomi, Pendapatan Asli Daerah Dan Dana Alokasi Umum Terhadap Pengalokasian Anggaran Belanja Modal Pada Pemerintah Kabupaten Buleleng. Jurusan Akuntansi Program S1. Volume: 2 No. 12014.

Novalia, Nanda Dwi. (2016). Pengaruh Pertumbuhan Ekonomi, Pendapatan Asli Daerah Dan Dana Alokasi Umum Terhadap Pengalokasian Anggaran Belanja Modal Pada Pemerintahan Daerah Kabupaten/Kota Di Provinsi Lampung. Skripsi fakultas ekonomi dan bisnis Universitas Lampung

Novianto, Trias Fajar dan Hastarini Dwi Atmanti. (2013). Analisis pengaruh pendapatan asli daerah, Investasi dan angkatan kerja terhadap Pertumbuhan PDRB Provinsi jawa tengah tahun 1992-2011. Diponegoro journal of economics. Volume 2, Nomor 2, Tahun 2013, Hal: 1-9

Pujiati, Amin. (2008). Analisis Pertumbuhan Ekonomi di Karesidenan Semarang di Era Desentralisasi Fiskal. Jurnal Ekonomi Pembangunan. Kajian Ekonomi Negara Berkembang. Hal: 61-70 